\title{
Determination of lotaustralin in Rhodiola species
}

AGNIESZKA GRYSZCZYŃSKA ${ }^{1 *}$, ZDZISŁAW ŁOWICKI ${ }^{1}$, BOGNA OPALA ${ }^{1}$, ANNA KRAJEWSKA-PATAN ${ }^{2}$, WALDEMAR BUCHWALD ${ }^{3}$, BOGUSŁAW CZERNY ${ }^{1,4}$, SEBASTIAN MIELCAREK ${ }^{1}$, PRZEMYSŁAW M. MROZIKIEWICZ ${ }^{1,5}$

'Department of Quality Control of Medicinal Products and Dietary Supplements Institute of Natural Fibres and Medicinal Plants

Libelta 27

61-707 Poznań, Poland

${ }^{2}$ Department of Pharmacology and Experimental Biology Institute of Natural Fibres and Medicinal Plants Libelta 27

61-707 Poznań

${ }^{3}$ Department of Botany, Breeding and Agricultural Technology Team of Botany and Agriculture of Medicinal Plants Institute of Natural Fibres and Medicinal Plants

Kolejowa 2

62-064 Plewiska/Poznań, Poland

${ }^{4}$ Department of General Pharmacology and Pharmacoeconomics Pomeranian Medical University

Żołnierska 48

70-204 Szczecin, Poland

${ }^{5}$ Laboratory of Experimental Pharmacogenetics

Department of Clinical Pharmacy and Biopharmacy

University of Medical Sciences

Św. Marii Magdaleny 14

61-861 Poznań, Poland

"corresponding author: tel.: +4861 6659550, fax: +4861 6659551, e-mail: agnieszka.gryszczynska@iwnirz.pl 
Sum mary

In our research, the concentration of lotaustralin in the roots of two species Rhodiola kirilowii and Rhodiola rosea were compared. Aqueous and hydroalcoholic extracts from those plants were analyzed too. To determine the content of this compound the ultra performance liquid chromatography - tandem mass spectrometry (UPLC-MS/MS, Waters) was used. The obtained results showed that the content of measured lotaustralin depends on the species of Rhodiola. $R$. rosea roots are the richer source of lotaustralin then $R$. kirilowii. The same situation was observed in the extracts. A hydroalcoholic extract from $R$. rosea contains up to $135.276 \mathrm{mg}$ of lotaustralin in $100 \mathrm{~g}$ of dry powdered material. In the case of $R$. kirilowii extracts, an aqueous extract contained more lotaustralin $(74.791 \mathrm{mg} / 100 \mathrm{~g}$ of dry powdered material) then a hydroalcoholic extract.

Key words: Rhodiola kirilowii, Rhodiola rosea, cyanogenic glucoside, lotaustralin, UPLC-MS/MS

\section{INTRODUCTION}

The phenomenon of cyanogenesis, the ability to release a hydrogen cyanide (HCN) from plant tissue, was been found in more than 2650 species of higher plants [1]. The most important source of HCN in the plants are mainly cyanogenic glycosides, cyanogenic lipids as well as processes of transformation of glyoxylate, hydroxylamine and ethylene [2,3]. It is well known that hydrogen cyanide is an effective inhibitor of cytochrome oxidase activity and is toxic to animals. Therefore, it is considered that cyanogenic glycosides are responsible for the protective function against herbivores and pathogens. Some of them, for example linamarin and lotaustralin are synthesized from valine and isoleucine, respectively and were found in various higher plants [4]. The research over the content of these compounds are mainly focused on the plants consumed in human diet as well as others used as herbal medicines, for example of Rhodiola species. Rhodiola has been used for centuries in the traditional folk medicine of Russia, Scandinavia and other countries $[5,6]$.

Review of the literature indicates that $R$. rosea, $R$. kirilowii and $R$. quadrifida are used as common medications. $R$. rosea has biological activities: antiallergenic and anti-inflammatory effects, enhanced mental alertness, stress-protective effects, lifespan increasing effects $[7,8]$. The main pharmacologically active chemical substances that are responsible for the beneficial properties of $R$. rosea, are polyphenolic compounds (phenylpropanoids, flavonoids, proanthocyanidins and tannins). The best-known active ingredients of anti-stress and antidepressant effects are rosavins, rosin, rhodiolin, salidroside and p-tyrosol. Rhizomes from $R$. rosea contain also essential oils $(0.05 \%)$ with monoterpene hydrocarbons, monoterpene alcohols and straight chain aliphatic alcohols [6,9]. In addition, the raw material and its preparations have significant antioxidant, antitumor and immunostimulatory activities. Moreover, it seems that Rhodiola rosea has a beneficial effect on the heart muscle and increases the intellectual functions [4]. 
R. kirilowii is used in traditional Chinese medicine as a source of compounds which have anti-anoxia and anticoagulative activity, decrease a saccharides level in blood and influence on cardiopulmonary disorders. Roots contain salidroside, p-tyrosol, daucosterol, $\beta$-sitosterol, lotaustralin, epigallocatechin gallate [10-15]. Peng and et al. found an toxic cyanogenic glucoside namely lotaustralin in $R$. kirilowii rhizome [14]. It was indicated that lotaustralin is also present in $R$. rosea [6]. According to Kang and Wang, this compound is present on the highest level in $R$. kirilowii among 10 analyzed Rhodiola species [16]. Lotaustralin can also be detected in cassava (Manihot esculenta Crantz), white clover (Trifolium repens), lima beans, Phaseolus lunatus L., Tetranychus urticae, Phytoseiulus persimilis [17]. During processing and chewing, lotaustralin can set free toxic hydrogen cyanide (HCN). Consumption of plant product containing this compound can cause acute poisoning, progression of Kenzo disease in women and detrimental effect on the development of central nervous system during pregnancy [18]. High content of cyanide in the human body causes dizziness, weakness, nausea, vomiting, diarrhoea and sometimes death [19]. In our experiment, we used two well-known species of Rhodiola: $R$. kirilowii and R. rosea, which were cultivated in the Institute of Natural Fibres and Medicinal Plants in Poznań. In these plants the content of lotaustralin was determined because this compound can be dangerous for the human health.

\section{MATERIAL AND METHODS}

\section{Plant material}

Rhodiola kirilowii and Rhodiola rosea used in the study were collected in October 2009 from field crops of the Institute of Natural Fibres and Medicinal Plants in Poznań. Roots were dried at a room temperature $\left(22-24^{\circ} \mathrm{C}\right)$.

\section{Preparation of plant extracts}

Subsequently, dry roots were powdered (0.315) and two kinds of extract were prepared: aqueous extract and $50 \%(v / v)$ ethanol extract.

\section{Preparation of aqueous extract}

The powdered dry roots were extracted with purified water for 3 hours at $90^{\circ} \mathrm{C}$ (material to solvent ratio 1:10). After filtering, the extracts were frozen at $-55^{\circ} \mathrm{C}$ and than lyophilised [2]. The dry plant extracts were stored at a temperature of $20-25^{\circ} \mathrm{C}$. 


\section{Preparation of 50\% (v/v) ethanol extract}

The powdered dry roots were extracted with $50 \%(\mathrm{v} / \mathrm{v})$ ethanol using the percolation method at plant material to solvent ratio 1:10. After the evaporation of the alcohol in reduced pressure at a temperature of $40-45^{\circ} \mathrm{C}$ the extracts were frozen at $-55^{\circ} \mathrm{C}$ and than lyophilised [2]. Dry plant extracts were stored at a temperature of $20-25^{\circ} \mathrm{C}$.

\section{Standards substances}

The following comparison substances were used in the experiment: lotaustralin (TRC) and linustain (SIGMA).

\section{Stock solutions}

Calibrate curves of lotaustralin as implemented standard from TRC and linustatin as a internal standard (Sigma Aldrich) were prepared. All substances were dissolved in methanol and different concentration of stock solutions were prepared. Calibration curves were prepared as 5 different levels of concentration at a range of $100-1000 \mathrm{ng} / \mathrm{ml}$.

\section{Sample preparation}

\section{Roots of Rhodiola}

About $2.0 \mathrm{~g}$ of dried powdered root from Rhodiola kirilowii or $1.5 \mathrm{~g}$ of dried powdered root from Rhodiola rosea was weighed out and placed in a $100 \mathrm{ml}$ roundbottom flask. To $20 \mathrm{ml}$ of $70 \%(\mathrm{v} / \mathrm{v})$ methanol $0.5 \mathrm{ml}$ of methanolic solution of linustatin (IS) was added. That sample was heated under a reflux condenser in the boiling point of the solvent for $45 \mathrm{~min}$ and after cooling, the sample was filtrated and extraction was repeated two more times. All extracts were connected to evaporate the methanol up to dry in a rotary evaporator in vacuum. A dry residue was dissolved in $3 \mathrm{ml}$ of $70 \%(\mathrm{v} / \mathrm{v})$ methanol. Sample was transferred quantitatively to $5 \mathrm{ml}$ volumetric flask for Rhodiola kirilowii and to $10 \mathrm{ml}$ for Rhodiola rosea. Subsequently, the solution was then made up to the mark with the $70 \%(v / v)$ methanol. The sample was filtered through a membrane filter with a diameter of $0.20 \mu \mathrm{m}$.

\section{Extracts from Rhodiola}

About $0.1 \mathrm{~g}$ of Rhodiola kirilowii or Rhodiola rosea extract was weighed out and placed in a $100 \mathrm{ml}$ round-bottom flask. To $20 \mathrm{ml}$ of $70 \%(\mathrm{v} / \mathrm{v})$ methanol $0.5 \mathrm{ml}$ of methanolic solution of linustatin (IS) was added. That sample was heated under a reflux 
condenser in the boiling point of the solvent for $45 \mathrm{~min}$ and after cooling, the sample was filtrated and extraction was repeated two more times. All extracts were connected to evaporate the methanol up to dry in a rotary evaporator in vacuum. A dry residue was dissolved in $3 \mathrm{ml}$ of $70 \%(\mathrm{v} / \mathrm{v})$ methanol. Sample was transferred quantitatively to $5 \mathrm{ml}$ volumetric flask for Rhodiola kirilowii and to $10 \mathrm{ml}$ for Rhodiola rosea. Subsequently, the solution was made up to the mark with the $70 \%(v / v)$ methanol. The sample was filtered through a membrane filter with a diameter of $0.20 \mu \mathrm{m}$.

\section{LC-MS/MS assay}

For determining concentration of lotaustarlin in the Rhodiola species the ultra performance liquid chromatography - tandem mass spectrometry (UPLC-ESI MS/ MS; Waters) was used. The separation of lotaustralin was performed on an Acquity UPLC BEH C18 column, $1.7 \mu \mathrm{m}, 2.1 \times 50 \mathrm{~mm}$ (Waters). Mobile phase: phase A: methanol, phase B: water. Mobile phase flow rate was: $0.25 \mathrm{ml} / \mathrm{min}$. The assay was performed in isocratic elution: $80 \%$ of phase $\mathrm{B}$. Column temperature was $24^{\circ} \mathrm{C}$; ion source temperature: $100^{\circ} \mathrm{C}$; desolvation temperature: $300^{\circ} \mathrm{C}$. Gas flow rate: desolvation gas: $700 \mathrm{~L} / \mathrm{h}$; cone gas: $10 \mathrm{~L} / \mathrm{h}$. That method of extraction was prepared to determine the concentration of lotaustralin in Rhodiola species. Fragmentation of lotaustralin $\mathrm{m} / \mathrm{z} 260 \rightarrow 161 \mathrm{Da}$ and internal standard linustatin $\mathrm{m} / \mathrm{z} 408 \rightarrow 323 \mathrm{Da}$. Lotaustralin and linustatin (IS) were analyzed in the negative-ions source.

\section{Validation}

Validation of this method of extraction and detection was conducted in accordance with the requirements of ICH. The calibrations curves were prepared on 5 different concentrations of substances. Retention time, peak area and regression coefficient were checked to accept recurrence and linearity of calibration curves. The calibration curves were prepared in the range $100-1000 \mathrm{ng} / \mathrm{ml}$. Then, the precision of extraction was done for six samples. The accurancy of this method was conducted on three different levels. The percentage of recovery ranged from 88.2 to $91.6 \%$. All validated parameters allowed to indicate that the extraction and detection methods are validated.

\section{Statistical method}

For lotaustralin and internal standard, the regression analysis was performed at 5 concentration levels. Concentration of lotaustralin was carried out for all samples in 6 repeats. The average and relative standard deviations (RSD) for those results were determined. 


\section{RESULTS}

The basic analytical and statistical parameters designed during the preparation of method are summarized in table 1. For the analytical method used in the study the precision, linearity and accuracy were determined. Precision and linearity were evaluated by using regression analysis for each of the comparison substances (tab. 2). The recovery of analytical method was analysed for $R$. kirilowii roots using the enrichment method by the addition of dry hydroalcoholic extract of $R$. rosea with the determined level of lotaustralin to the sample. Figure 1 presents the MRM chromatogram showing fragmentation of cyanogenic glucoside in Rhodiola kirilowii and figure 2 concerns Rhodiola rosea roots. Detection of every analysed compound was conducted in negative ions source. The signals visible in the chromatogram came from the parent ion fragmentation $[\mathrm{M}-\mathrm{H}] \cdot$. The content of lotaustralin in 2 different species of Rhodiola was presented in the table 3. Comparing the results of the roots, $R$. rosea contained a higher quantity of lotaustralin ( $10.880 \mathrm{mg} / 100 \mathrm{~g}$ of dry powdered material) then $R$. kirilowii (3.226 $\mathrm{mg} / 100 \mathrm{~g}$ of dry powdered material). In the both cases, concentration of lotaustralin in the extracts was higher then in the roots. As shown, the aqueous extract from $R$. kirilowii contained $74.791 \mathrm{mg} / 100 \mathrm{~g}$ of dry powdered material of lotaustralin and was richer in this compound then hydroalcoholic extract. In $R$. rosea, richer source of cyanogenic glucoside was hydroalcoholic extract $(135.276 \mathrm{mg} / 100 \mathrm{~g}$ of dry powdered material).

Table 1 .

Characteristic parameters of cyanogenic glucoside detection

\begin{tabular}{lcccc}
\hline \multicolumn{1}{c}{ Compound } & Retention time $[\mathrm{min}]$ & $\mathrm{RSD}_{\mathrm{t}}(n=15)[\%]$ & $\operatorname{RSD}_{\mathrm{p}}(n=5)[\%]$ & Fragmentation $\mathrm{m} / \mathrm{z}[\mathrm{Da}]$ \\
\hline Lotaustralin & 1.44 & 0.34 & 4.88 & $260 \rightarrow 188$ \\
\hline Linustatin $(\mathrm{IS})$ & 0.82 & 0.43 & 1.62 & $408 \rightarrow 323$ \\
\hline
\end{tabular}

$R S D_{t}$ - relative standard deviation of retention time

$\operatorname{RSD}_{\mathrm{p}}$ - relative standard deviation of peak area

Table 2 .

Method recovery $(n=3)$

\begin{tabular}{cc}
\hline Sample & Lotaustralin $[\% \pm \mathrm{RSD}]$ \\
\hline $20 \%$ & $88.2 \pm 4.3$ \\
\hline $40 \%$ & $91.6 \pm 6.8$ \\
\hline $80 \%$ & $90.0 \pm 3.7$ \\
\hline
\end{tabular}

RSD - relative standard deviation 
Table 3 .

Content of cyanogenic glucoside in Rhodiola kirilowii and Rhodiola rosea roots and extracts

\begin{tabular}{lcc}
\hline \multirow{2}{*}{ Sample } & \multicolumn{2}{c}{ Lotaustralin } \\
\cline { 2 - 3 } & $\begin{array}{c}\text { Content }[\mathrm{mg} / 100 \mathrm{~g} \text { of dry } \\
\text { powdered material] }\end{array}$ & RSD [\% $]^{*}$ \\
\hline Rhodiola kirilowii root & 3.226 & 1.57 \\
\hline 50\% ethanol extract & 53.773 & 2.03 \\
\hline aqueous extract & 74.791 & 2.83 \\
\hline Rhodiola rosea root & 10.880 & 3.03 \\
\hline 50\% ethanol extract & 135.276 & 1.74 \\
\hline aqueous extract & 106.582 & 2.42 \\
\hline
\end{tabular}

* - RSD - relative standard deviation $(n=6)$
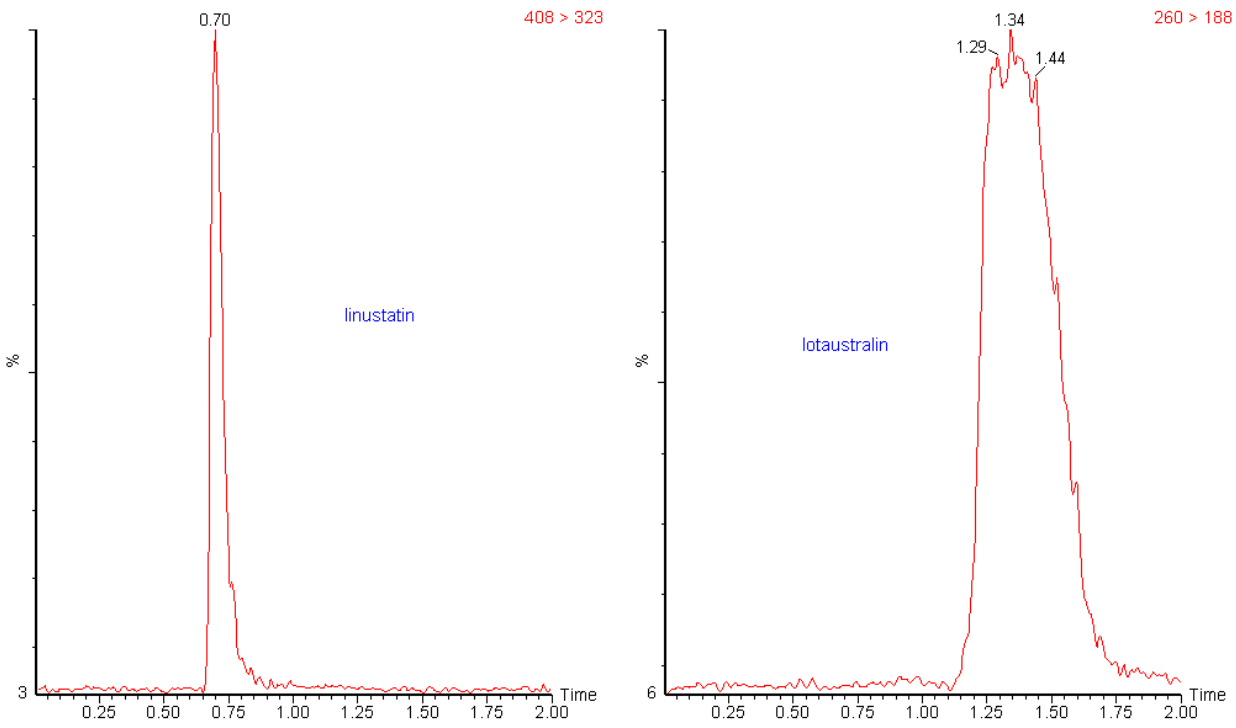

Figure 1.

The MRM chromatogram showing fragmentation of cyanogenic glucoside from Rhodiola kirilowii roots. 

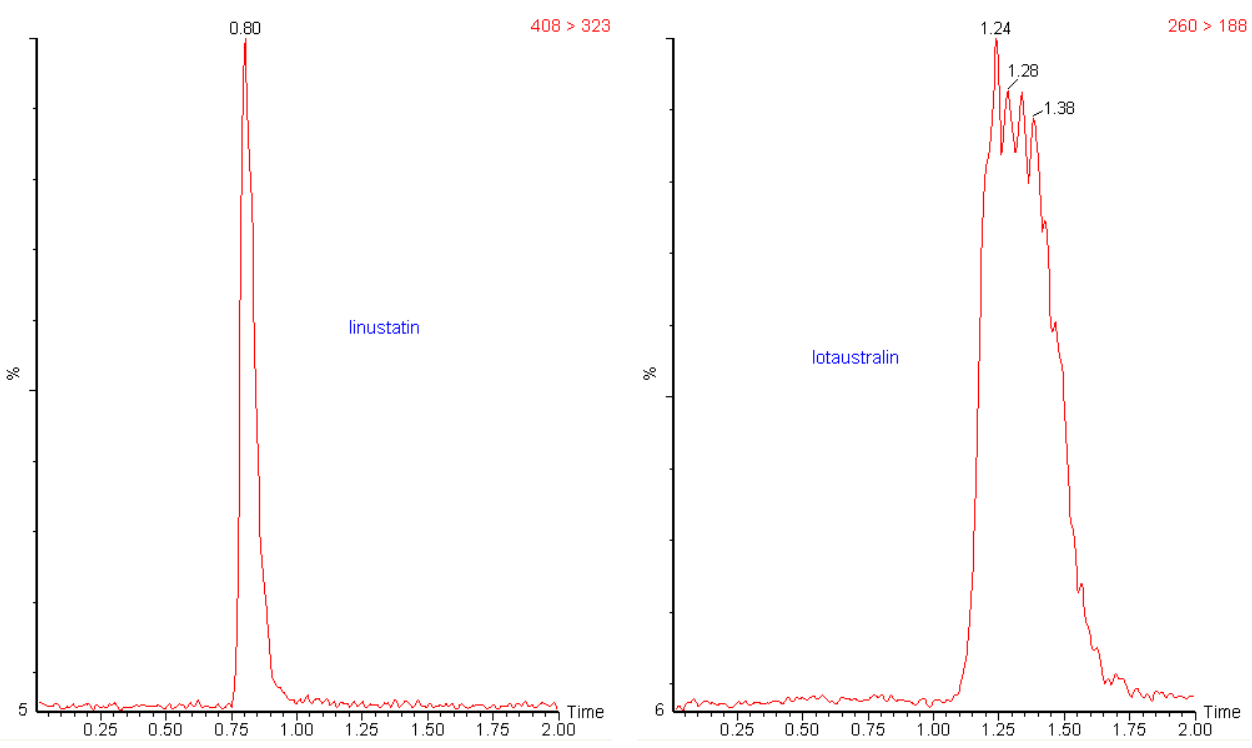

Figure 2.

The MRM chromatogram showing fragmentation of cyanogenic glucoside from Rhodiola rosea roots.

\section{DISCUSSION}

In recent years, modern and sensitive methods of the detection of plant compounds including those with toxic activity are used. Therefore, we have made attempts in our Department to analyze one of these types of compounds - lotaustralin. The structure of lotaustralin was determined by Akgul et al. using spectroscopic methods [20]. It has been shown that this component is present in the methanol extract from the roots of Rhodiola rosea as a mixture of two diastereoisomers form [20]. So far, the research on the lotaustralin content in Rhodiola rosea and Rhodiola kilirowii using HPLC techniques conducted Xiao (2005) and Wiedenfeld et al. (2007), respectively $[21,10]$. We used the ultra performance liquid chromatography - tandem mass spectrometry (UPLC-ESI MS/MS; Waters) to determine the concentration of lotaustralin in Rhodiola root extracts. This method of detection allows the identification of lotaustralin using the fragmentation of parent ion. Among the herbal materials used in this study, the roots of $R$. rosea contained a higher amount of lotaustralin then $R$. kirilowii. In both cases, concentration of lotaustralin in the extracts was higher then in the roots. The results of our study showed that the highest concentration of cyanogenic glucoside was found in hydroalcoholic extract of $R$. rosea ( $135.276 \mathrm{mg} / 100 \mathrm{~g}$ of dry powdered material). Aqueous extracts of $R$. rosea and $R$. kirilowii contain much less lotaustralin than the hydroalcoholic one. It is recognized that content of this toxic ingredient depends 
on the species and the habitat of the plant [16]. Moreover, according to several authors, the concentration of cyanogenic compounds in plants varies significantly duringgrowing season depending on the type of mineral nutrition and a number of environmental factors [1, 22-24].

\section{CONCLUSION}

In summary, we showed that the method the ultra performance liquid chromatography - tandem mass spectrometry (UPLC-ESI MS/MS) method can be successfully used for the determination of lotaustralin in the extracts of roots of Rhodiola species. Due to the fact that Rhodiola rosea is an endangered medicinal species having a important pharmacological properties, it is necessary to conduct further studies regarding the content of beneficial and undesirable metabolites in root extracts.

\section{ACKNOWLEDGEMENT}

This research project was suported by the Ministry of Science and Higher Education, grant No. N N405 306136.

\section{REFERENCES}

1. Siegien I. Cyanogenesis in plants and its role in herbivore defense. Kosmos. Problemy Nauk Biologicznych 2007; 56 1-2 (274-275):155-166.

2. Seigler DS. Cyanogenic glycosides and cyanolipids. [In:] Seigler DS. Plant Secondary Metabolism. Kluwer Academic Press, Boston 1998; 273-296.

3. Yip W-K, Yang SF. Cyanide metabolism in relation to ethylene production in plant tissues. Plant Physiol 1988; 88:473-476.

4. Zilg H, Conn EE. Stereochemical aspects of lotaustralin biosynthesis. J Biol Chem 1974; 249(10):3112-3115.

5. Wolski T, Baj T, Ludwiczuk A, Głowniak K, Czarnecka G. Rhodiola genus taxonomy chemical composition, activity and use also phyochemical analysis of roots of two species of Rhodiola: Rhodiola rosea $\mathrm{L}$. and Rhodiola quadrifida (Pall.) Fish et Mey. Postępy Fitoterapii 2008; 11(1):2-14.

6. Gryszczyńska A, Mielcarek S, Buchwald W. The determination of flavan-3-ol content in the root of Rhodiola Kirilowii. Herba Pol 2011; 51(1): 27-37.

7. Yousef GG , Grace MH, Cheng DM, Belolipov IV, Raskin I, Lila MA. Comparative phytochemical characterization of three Rhodiola species. Phytochemistry 2006; 67:2380-2391.

8. Assessment report on Rhodiola rosea L., rhizoma et radix. Committee on Herbal Medicinal Products (HMPC), EMA/HMPC/232100/2011, 27 March 2012.

9. Panossian A, Wikmana G, Sarris J. Rosenroot (Rhodiola rosea): Traditional use, chemical composition, pharmacology and clinical efficacy. Phytomedicine 2010; 17(7):481-493.

10. Wiedenfeld H, Zych M, Buchwald W, Furmanowa M. New compounds from Rhodiola kirilowii. Sci Pharm 2007;75:29-34.

11. Krajewska-Patan A, Furmanowa A, Mścisz A, Dreger M, Łowicka A, Górska-Paukszta M, et al. Tissue culture of Rhodiola Kirilowii (Regel.) Maxim - contents of biologically active compounds at different stages of growth. Herba Pol 2006; 52(4):98-106. 
12. Kang S, Wang J, Zhang J, Liu FY, Xu Z. The isolation and identification of p-hydroxyphenrthyl B-dglycoside (salidroside) and lotaustralin in 10 species of Rhodiola using GC are reported. Chin Mater Med 1998; 23:365-366.

13. Kang S, Zhang J, Lu Y, Lu D. Chemical constituents of Rhodiola Kirilowii (Reg.) Reg. Chung Kuo Chung Yao Tsa Chih 1992; 17:100-101.

14. Peng N, Ma CY, Ge YC. Chemical constituents of Rhodiola Kirilowii Regel. Zhongguo Zhong Yao Za Zhi 1994; 19(11):676-7, 702.

15. Zhang S, Wang J, Zhang H. Chemical costituents of Tibetan medicinal herb Rhodiola Kirilowii (Reg.) Reg Zhongguo Zhong Yao Za Zhi 1991; 16(8):483-512.

16. Kang S, Wang J. Comaprative study of the constituents from 10 Rhodiola plants. Zhong Yao Cai 1997; 20(12):616-8.

17. Rojas MG, Morales-Ramo JA. Tri-trophic level impact of host plant linamarin and lotaustralin on Tetranychus urticae and its predator Phytoseiulus persimilis. J Chem Ecol 2010; 36:1354-1362.

18. Nyirenda DB, Chiwona-Karltun L, Chitundu M, Haggblade S, Brimer L. Chemical safety of cassava products in regions adopting cassava production and processing - Experience from Southern Africa, Food Chem Toxic 2011; 49:607-612.

19. Burns AE, Howard Bradbury J, Cavagnaro TR, Gleadow RM. Total cyanide content of cassava food products in Australia. J Food Comp Anal 2011; 25:79-82.

20. Akgul Y, Ferreira D, Abourashed EA, Khan IA. Lotaustralin from Rhodiola rosea roots. Phytochemical Communications. Fitoterapia 2004; 75:612-614.

21. Xiao WQR. Quantitative Analysis of Salidroside, Tyrosol and Lotaustralin in Roots of Rhodiola L. Plants Grown at Tianshan Mountain. Chinese J Pharmaceut Anal 2005; 09:1026-1029.

22. Stochmal A, Oleszek W. Changes of cyanogenic glucosides in white clover (trifolium repens l.) during the growing season. J Agric Food Chem 1997; 45:4333-4336.

23. Busk PK, Moller BL. Dhurrin synthesis in sorghum is regulated the transcriptional level and induced by nitrogen fertilization in older plants. Plant Physiol 2002; 129(3):1222-31.

24. Vetter J. Plant cyanogenic glycosides. Toxicon 2000; 38:11-36.

\title{
OZNACZANIE ZAWARTOŚCI LOTAUSTRALINY W GATUNKACH RHODIOLA
}

AGNIESZKA GRYSZCZYŃSKA ${ }^{1 *}$, ZDZISŁAW ŁOWICKI ${ }^{1}$, BOGNA OPALA ${ }^{1}$, ANNA KRAJEWSKA-PATAN ${ }^{2}$, WALDEMAR BUCHWALD ${ }^{3}$, BOGUSŁAW CZERNY ${ }^{1,4}$, SEBASTIAN MIELCAREK ${ }^{1}$, PRZEMYSŁAW M. MROZIKIEWICZ ${ }^{1,5}$

\author{
'Zakład Badania Jakości Produktów Leczniczych i Suplementów Diety \\ Instytut Włókien Naturalnych i Roślin Zielarskich \\ ul. Libelta 27 \\ 60-707 Poznań
}

\section{${ }^{2}$ Zakład Farmakologii i Biologii Doświadczalnej Instytut Włókien Naturalnych i Roślin Zielarskich \\ ul. Libelta 27 \\ 60-707 Poznań}


${ }^{3}$ Zespół Botaniki i Agrotechniki Roślin Zielarskich Zakład Botaniki, Hodowli i Agrotechniki Instytut Włókien Naturalnych i Roślin Zielarskich ul. Kolejowa 2

62-064 Plewiska k/Poznania

${ }^{4}$ Zakład Farmakologii Ogólnej i Farmakoekonomiki Wydział Nauk o Zdrowiu, Pomorski Uniwersytet Medyczny

ul. Żołnierska 48

70-204 Szczecin

${ }^{5}$ Pracownia Farmakogenetyki Doświadczalnej

Katedra i Zakład Farmacji Klinicznej i Biofarmacji

Uniwersytet Medyczny w Poznaniu

ul. Św. Marii Magdaleny 14

61-861 Poznań

*autor, do którego należy kierować korespondencję: tel.: +4861 6659550, faks: +4861 6659551, e-mail: agnieszka.gryszczynska@iwnirz.pl

Streszczenie

W badaniach przeprowadzonych w Instytucie Włókien Naturalnych i Roślin Zielarskich porównano zawartość lotaustraliny w dwóch gatunkach roślin: Rhodiola kirilowii i Rhodiola rosea, jak również w przygotowanych z tych roślin dwóch wyciągach: wodnym oraz wodnoalkoholowym (50\% etanolowy wyciąg). W celu wyznaczenia zawartości lotaustraliny wykorzystano ultrasprawny chromatograf cieczowy sprzężony z tandemowym spektrometrem mas (UPLC-MS/MS, Waters). Wykazano, że zawartość cyjanogennego glukozydu zależna jest od gatunku. Przeprowadzona walidacja metody pozwala na satysfakcjonujące wykorzystanie tej metody w badaniach zawartości lotaustraliny.

Słowa kluczowe: Rhodiola kirilowii, Rhodiola rosea, cyjanogenny glukozyd, lotaustralina, UPLC-MS/MS 